\title{
HUBUNGAN KEBIASAAN MEROKOK DENGAN KEJADIAN TB PARU
}

Fitrya Ayu Nur Aini AR, Setiawan, Pratiwi Hermiyanti*

Jurusan Kesehatan Lingkungan Poltekkes Kemenkes Surabaya

*Email korespondensi: pratiwi@poltekkesdepkes-sby.ac.id

\begin{abstract}
ABSTRAK
TB paru ditularkan melalui media udara ketika penderita TB paru batuk, bersin, berbicara atau meludah. Data Litbangkes, perokok mempunyai risiko menderita TB 3 kali lebih tinggi dibandingkan dengan mereka yang tidak merokok. Penyakit TB Paru setiap tahunnya masuk kedalam 10 besar penyakit yang sering terjadi di masyarakat mengingat penyebaran penyakit TB Paru juga sangat cepat. Penelitian ini bertujuan untuk mengetahui kebiasaan merokok dari penderita TB Paru.

Penelitian ini menggunakan metode studi literatur. Variabel yang diteliti adalah variabel bebas yaitu kebiasaan merokok dan variabel terikat yaitu kejadian TB Paru. Analisa data dilakukan dengan membandingkan beberapa literatur untuk dapat ditarik sebuah kesimpulan yang disajikan dalam bentuk tabel.

Hasil studi literatur dapat dijelaskan bahwa kebiasaan merokok berpengaruh terhadap kejadian TB Paru. Menurut studi literatur, responden penderita TB Paru tidak bisa meninggalkan kebiasaan merokok, bahkan ada beberapa responden yang mengaku mengalami kegagalan dalam pengobatan TB Paru yang sudah dijalani selama berbulanbulan karena tidak bisa berhenti merokok. Uji statistik dari 5 artikel yang menjadi bahan studi literatur menunjukkan bahwa terdapat hubungan antara kebiasaan merokok dengan kejadian TB Paru.

Kesimpulan dari studi literatur, terdapat hubungan antara kebiasaan merokok dengan kejadian TB Paru. Saran yang dapat diberikan kepada petugas kesehatan adalah intensif melakukan penyuluhan terhadap masyarakat tentang efek dari kebiasaan merokok terhadap penyakit TB Paru.
\end{abstract}

Kata kunci: kebiasaan merokok, TB Paru

\section{PENDAHULUAN}

Tuberkulosis (TB) adalah suatu penyakit infeksi menular yang disebabkan bakteri Mycobacterium tuberculosis, yang dapat menyerang berbagai organ, terutama paru-paru. TB ditularkan melalui udara (melalui percikan dahak pasien TB) ketika seseorang yang sakit TB batuk, bersin, berbicara atau meludah. Percikan dahak pasien TB tersebut didalamnya mengandung kuman TB atau bacilli yang disebarkan ke udara. Orang dapat terpapar TB hanya dengan menghirup sejumlah kecil kuman TB. Pasien TB dengan status TB Basil Tahan Asam (BTA) positif dapat menularkan sekurangkurangnya kepada 10-15 orang lain setiap tahunnya. Sepertiga dari populasi dunia sudah tertular dengan TB (Profil Kesehatan Indonesia, 2013). Penyakit TB diderita jutaan orang pertahun dan bersama HIV menjadi penyebab kematian utama di seluruh dunia (WHO, 2015).

Indonesia menempati urutan ke-3 pengonsumsi rokok di dunia yaitu $28 \%$
(65 juta penduduk Indonesia) atau 1 dari 4 penduduk. Data dari Badan Penelitian dan Pengembangan Kesehatan (Litbangkes) menunjukkan bahwa mereka yang merokok (termasuk mereka yang masih merokok dan yang telah berhenti merokok) mempunyai risiko menderita TB 3 kali lebih tinggi dibandingkan dengan mereka yang tidak merokok. Paparan tembakau baik secara aktif maupun pasif dapat meningkatkan risiko terkena TB. Risiko terkena TB akan meningkat 9 kali lipat apabila ada 1 perokok dalam satu rumah (Profil Kesehatan Indonesia, 2013). Penyakit TB dapat menyerang seseorang pada semua umur dan jenis kelamin. Terdapat perkiraan penderita TB Paru di sarana kesehatan di Indonesia adalah sekitar 511.873 penderita dari berbagai umur dan jenis kelamin (profil kesehatan Indonesia, 2018)

Prevalensi perokok setiap hari yaitu $24,6 \%$. Proporsi perokok terbanyak setiap hari yaitu pada umur 30 tahun sebesar 
$33,4 \%$, umur $35-39$ tahun $32,2 \%$, sedangkan proporsi perokok setiap hari pada laki-laki lebih banyak dibandingkan perempuan (47,5\% banding1,1\%). Kejadian TB Paru di Provinsi Jawa Timur pada tahun 2018 adalah sebanyak 56.445 penduduk dari semua jenis umur (Profil Kesehatan RI, 2018).

Penyakit TB Paru setiap tahunnya masuk kedalam 10 besar penyakit yang sering terjadi di masyarakat mengingat penyebaran penyakit TB Paru juga sangat cepat. Penyakit yang disebabkan oleh bakteri yang bisa didukung oleh perilaku yang tidak sehat dan keadaan fisik rumah yang tidak memadai ini jika tidak ditangani dapat menyebabkan kematian. Pada tahun 2017 jumlah TB Paru di Kabupaten Nganjuk adalah sekitar 431 orang dari jumlah penduduk yang mencapai 1 juta penduduk. (Profil Kesehatan Kabupaten Nganjuk, 2017)

Berdasarkan hasil Riset Kesehatan Dasar (Riskesdas, 2013) prevalensi TB paru masih berada diposisi yang sama untuk tahun 2007-2013 yaitu (0,4\%), menurut karakteristik jenis kelamin lakilaki sebesar $(0,4 \%)$ lebih rendah dari perempuan yaitu $(0,3 \%)$. Dalam profil kesehatan 2013 angka notifikasi kasus Basil Tahan Asam BTA (+) pada tahun 2013 di Indonesia sebesar 81,0 per 100.000 penduduk dan provinsi tertinggi yaitu Sulawesi Utara 224,2 per 100.000 penduduk. Beberapa penelitian menyebutkan bahwa salah satu penyebab TB paru adalah gaya hidup (lifestyle), pada penelitian Sarwani dan Nurleila (2012) merokok dan TB paru menunjukan ada hubungan yang signifikan antara merokok dan TB paru, dan di temukan bahwa separuh dari kematian karena TB paru pada laki-laki disebabkan merokok dan 3,2 dari perokok berkembang menjadi penderita TB paru. Kematian pada penderita merokok (Gajalakshmi, 2003 dalam Sarwani dan Nurleila, 2011).

Dalam jurnal Kholis Ernawati, dkk mengemukakan bahwa orang yang mengkonsumsi rokok tiap hari sebanyak 593 orang $(33,4 \%)$, sedangkan yang tidak pernah sama sekali mengkonsumsi rokok sebanyak 856 orang $(48,2 \%)$ yang menunjukkan bahwa tidak ada hubungan antara kebiasaan merokok dengan kejadian TB Paru di Provinsi Sulawesi Utara berdasarkan data Riskesdas tahun 2010. Sedangkan menurut penelitian dari Alfah Yulied Lalombo,dkk mengemukakan bahwa hasil penelitian yang dilakukan dengan chi square yang nilai harapannnya $<5$, didapatkan hasil yaitu $p=0,01$ yang berarti dengan nilai $p$ lebih kecil dari nilai $a=0,05$ yang berarti bahwa dari hasil penelitian mengenai hubungan kebiasaan merokok dengan kejadian TB paru di Puskesmas Siloam Kecamatan Tamako Kabupaten Kepulauan Sangihe, Ada hubungan kebiasaan merokok dengan kejadian Tuberkulosis Paru paru di Puskesmas Siloam Kecamatan Tamako.

Puskesmas Ngronggot telah melayani masyarakat yang termasuk dalam cakupan Puskesmas Ngronggot. Menurut data hasil rekap dari Puskesmas Ngronggot tahun 2019 masyarakat yang menderita TB Paru dan sedang melakukan pengobatan adalah sebanyak 22 penduduk yang terkena penyakit TB paru dan berjenis kelamin laki-laki dan masuk dalam urutan ke-4 puskesmas yang memiliki pasien TB terbanyak sekabupaten Nganjuk. Penderita yang digunakan sebagai sampel adalah yang berjenis kelamin laki-laki karena merokok dapat memperlemah paru dan menyebabkan paru lebih mudah terinfeksi kuman tuberkulosis. TB dapat ditularkan melalui udara sebab itu TB Paru gampang menular dan jika penanganannya terlambat dapat berakibat fatal yaitu kematian. Tujuan dari penelitian ini adalah mengetahui hubungan kebiasaan merokok dengan kejadian TB Paru.

\section{METODE PENELITIAN}

Jenis penelitian yang digunakan adalah studi literatur dengan membandingkan beberapa artikel penelitian untuk mengetahui hubungan kebiasaan merokok dengan kejadian TB Paru. Artikel yang digunakan menggunakan database dari google scholar dan pubmed dengan kurun waktu publikasi 10 tahun terakhir.

Artikel yang telah didapat sebagian besar metode yang digunakan untuk analisa data adalah uji analitik dengan chi square dengan nilai a sebesar 0,05 dan ada satu jurnal yang menggunakan 
metode perhitungan OR untuk analisa. Hasil yang didapatkan adalah melalui lembar kuesioner dan wawancara terhadap responden. Data yang telah dikumpulkan kemudian dianalisis dan disintesis untuk dapat dilakukan pembahasan.

\section{HASIL DAN PEMBAHASAN Karakteristik Responden Penderita TB Paru}

Karakteristik responden merupakan data diri dari responden yang meliputi umur, jumlah anggota keluarga, pendidikan terakhir, dan pekerjaan. Hal ini digunakan untuk mengetahui apakah karakteristik responden tersebut juga menjadi faktor terjadinya penyakit TB Paru pada responden. Dismo Katiandagho (2018) menyatakan bahwa responden dengan jenis kelamin laki-laki lebih banyak dibandingkan dengan responden perempuan hal ini dikarenakan jumlah perokok pada laki-laki lebih besar dibanding dengan perempuan dan dari hasil wawancara yang telah dilakukan responden tidak dapat berhenti merokok karena sudah ketergantungan, walaupun responden mengetahui efek samping dari kebiasaan merokok dan beberapa responden menyatakan bahwa selalu mengkonsumsi rokok setelah makan sedangkan untuk yang berjenis kelamin perempuan menjadi perokok pasif karena ada anggota keluarga yang merokok didalam rumah, ia juga menggambarkan distribusi pendidikan responden dimana lebih banyak responden dengan tingkat pendidikan terakhir SD dan SMA sedangkan responden dengan pendidikan terakhir SMP dan Perguruan Tinggi lebih sedikit dan sebagian besar responden memilii pekerjaan sebagai petani. Sedangkan Laila Romlah (2015) menyatakan bahwa ada hubungan yang signifikan antara tidak sekolah sesuai ketentuan yaitu 9 tahun dengan kejadian TB Paru dengan besar resiko 2 kali dibandingkan dengan yang melaksanakan sekolah wajib 9 tahun,dan jenis kelamin tidak memiliki hubungan yang signifikan dengan kejadian TB Paru sedangkan umur dan pekerjaan bersifat proteksi terhadap kejadian TB Paru.

\section{Hubungan Kebiasaan Merokok dengan Kejadian TB Paru}

Berdasarkan hasil yang tercantum dalam jurnal yang sejalan dengan penelitian ini ditunjukkan bahwa secara umum kebiasaan menjadi salah satu faktor yang dapat mempengaruhi terjadinya penyakit TB Paru. Hal ini dibuktikan dari hasil observasi yang telah dilakukan peneliti sesuai dengan data nyata dari lapangan dengan pengisian kuesioner yang sudah disediakan sebagai alat ukur melalui pertanyaan-pertanyaan yang berkaitan dengan kebiasaan merokok pada responden yang kemudian diperkuat dengan uji analitik.

Kebiasaan merokok menurut status merokok seseorang dapat dikelompokkan dalam kelompok bukan perokok, perokok dan bekas perokok. Bukan perokok adalah orang yang tidak pernah merokok atau merokok kurang dari 100 sigaret selama hidupnya. Perokok adalah orang yang merokok lebih dari 100 sigaret sepanjang hidupnya dan saat ini masih merokok atau telah berhenti merokok kurang dari satu tahun. Bekas perokok adalah orang yang merokok lebih dari 100 sigaret sepanjang hidupnya dan telah berhenti merokok lebih dari satu tahun.

Wahid Tri Wahyudi (2017) menyatakan bahwa merokok merupakan salah satu faktor yang menyebabkan terjadinya TB Paru, ini dikarenakan kebiasaan merokok dapat merusak sistem kerja dan pertahanan paru-paru sehingga semakin lama orang mengkonsumsi rokok maka semakin beresiko untuk terkena TB Paru. Penelitian ini sejalan dengan penelitian yang dilakukan oleh Dismo Katiandagho (2018) yang menyatakan bahwa terdapat hubungan yang signifikan antara kebiasaan merokok dengan kejadian TB Paru dan orang yang merokok dengan kurun waktu > 10 tahun beresiko 2 kali lebih besar untuk terkena TB Paru dibandingkan dengan orang yang tidak mengkonsumsi rokok, melalui wawancara yang telah dilakukan responden yang memiliki kebiasaan merokok dan terkena TB Paru mengaku tidak dapat berhenti merokok karena sudah ketergantungan walaupun sudah mengetahui bahaya dari merokok, perilaku merokok dari penderita TB Paru sudah berlangsung selama 
bertahun-tahun dan tetap tidak berhenti merokok meskipun sudah dinyatakan positif terkena TB Paru, merokok dengan kejadian TB Paru merupakan masalah ganda karena merokok membantu penyebaran infeksi dan memperburuk tingkat keparahan penyakit Tuberkulosis. Penelitian ini diperkuat oleh penelitian yang dilakukan oleh Yuliyanti Purnamasari (2010) yang menyatakan bahwa kebiasaan merokok merupakan faktor resiko untuk terjadinya infeksi TB Paru, selanjutnya infeksi dapat berkembang menjadi penyakit dan beresiko kematian hampir $60 \%$ kematian penderita tuberkulosis berkaitan dengan kebiasaan merokok responden. Asap rokok dalam jumlah yang besar yang dihirup dapat meningkatkan risiko keparahan, kekambuhan dan kegagalan dalam pengobatan tuberkulosis, pajanan rokok menyebabkan kelainan pada mukosa saluran napas kapasitas ventilasi maupun fungsi kapiler, merokok juga dapat memperlemah fungsi paru sehingga lebih mudah terinfeksi kuman tuberkulosis. Ryan Arvisza Falletehan (2014) juga menyatakan bahwa terdapat hubungan antara perilaku merokok dengan kejadian Tuberkulosis Paru, dari hasil penelitian yang telah dilakukan terdapat lebih besar pada perokok hal ini dikarenakan mekanisme yang menyebabkan antara lain adalah adanya penurunan fungsi mukosiliar, adanya kerusakan epitel dan peradangan, penyempitan kantung udara alveolar, peningkatan jumlah makrofag alveolar beredar. Selain perubahan fisik, penekanan terhadap kekebalan tubuh seorang perokok dapat berkontribusi terhadap infeksi tuberkulosis. Laila Romlah (20) juga menyatakan bahwa terdapat hubungan antara merokok dengan kejadian TB Paru, ia menyebutkan bahwa merokok merupakan salah satu faktor resiko TB Paru, merokok memiliki resiko lebih besar untuk terkena TB Paru dibandingkan dengan orang yang tidak merokok, hal ini karena banyak kandungan berbahaya yang ada didalam rokok diantaranya gas $\mathrm{CO}$, nikotin, dan tar. Bahan-bahan kimia tersebut dapat membahayakan bagi tubuh, nikotin merupakan racun yang mematikan semakin banyak nikotin yang dikonsumsi, maka semakin tinggi pula resiko untuk terkena penyakit-penyakit akibat rokok, hal ini dikarenakan nikotin dapat terakumulasi didalam hati, ginjal, lemak dan paru-paru, nikotin dapat merangsang terjadinya sejumlah reaksi kimia yang mempengaruhi hormon seperti adrenalin, dopamine, dan insulin sehingga membuat sensasi yang nikmat pada rokok seketika tetapi sensasi ini hanya berlangsung sementara, sehingga membuat orang yang menghisapnya menjadi kecanduan. Gas CO mempunyai kemampuan untuk mengikat hemoglobin yang terdapat dalam sel darah merah lebih kuat jika dibandingkan dengan oksigen sehingga setiap ada asap tembakau, selain kadar oksigen yang berkurang sel darah merah juga akan semakin kekurangan oksigen dikarenakan yang diangkut merupakan gas CO bukan oksigen, terpaparnya gas CO dalam jumlah yang besar dapat menyebabkan hilangnya kesadaran hingga meninggal dunia. Tar dapat menyebabkan perubahan struktur dan funsgi saluran nafas dan jaringan paruparu, serta respon imunologis pejamu terhadap infeksi.

\section{KESIMPULAN}

Berdasarkan penelitian yang telah dilakukan dapat disimpulkan bahwa penderita TB paru adalah jenis kelamin laki-laki. Terdapat hubungan antara kebiasaan merokok dengan terjadinya infeksi TB Paru.

\section{SARAN}

Berdasarkan penelitian yang telah dilakukan disaran sebagai berikut:

1. Petugas Kesehatan perlu melakukan penyuluhan terhadap masyarakat tentang efek dari kebiasaan merokok dan penyakit TB Paru.

2. Bagi masyarakat yang mempunyai kebiasaan merikok sabaiknya mengurangi bahkan kalau bisa berhenti dari kebiasaan merolok, karena sangat berbahaya bagi kesehatan.

3. Hasil penelitian ini diharapkan dapat digunakan sebagai acuan atau reverensi untuk penelitian lebih lanjut, dengan menggunakan metode analisis yang berbeda 


\section{DAFTAR PUSTAKA}

Ernawati Kholis, Artha Susila B Duarsa, Rifda Wulansari, Lu'lu Zamzami. (2010). Hubungan Merokok Dengan Kejadian Tuberkulosis Paru di Provinsi Sulawesi Utara Berdasarkan Data Riskesdas Tahun 2010. Jakarta. Jurnal Kedokteran

Falletehan Ryan Arvisza. (2014). Hubungan Perilaku Merokok Dengan Kejadian Tuberkulosis Paru Di Balai Besar Kesehatan Paru Masyarakat (BBPKM) Surakarta. Fakultas Kedokteran. Universitas Muhammadiyah Surakarta. Surakarta

Katiandagho Dismo, Vega Roosa Fione, Joy Sambuaga. (2018). Hubungan Merokok Dengan Kejadian TB Paru Di Wilayah Kerja Puskesmas Tatelu Kecamatan Dimambe. Manado. Jurnal Kesehatan Lingkungan.

Kementerian Kesehatan Republik Indonesia. (2011). Pedoman Nasional Pengendalian Tuberkulosis.

Lalombo Alfah Yulied, Henry Palandeng, Vanry D. Kallo. (2015). Hubungan Kebiasaan Merokok Dengan Kejadian Tuberkulosis Paru Di Puskesmas Siloam Kecamatan
Tamako Kepulauan Sangihe. Manado. Jurnal Keperawatan

Profil Kesehatan RI. (2018). Profil Kesehatan Indonesia 2018. Kementerian Kesehatan Republik Indonesia 2019

Profil Kesehatan. (2017). Profil Kesehatan Kabupten Nganjuk 2017. Dinas Kesehatan Kabupaten Nganjuk

Profil Kesehatan Indonesia. (2013). Profil Kesehatan Indonesia 2013. Kementerian Kesehatan RI 2014

Purnamasari Yuliyanti. (2010). Hubungan Merokok Dengan Angka Kejadian Tuberkulosis Paru Di RSUD Dr.Moewardi Surakarta. Fakultas Kedokteran. Universitas Sebelas Maret. Surakarta

Romlah Laila. (2015). Hubungan Merokok Dengan Kejadian Penyakit Tuberkulosis Paru Di Wilayah Kerja Puskesmas Setu Kota Tangerang Selatan. Fakultas Kedokteran dan Ilmu Kesehatan. Universitas Islam Negeri Syarif Hidayatullah. Jakarta

Sarwani Dwi, Sri Nurlela. (2012). Merokok dan Tuberkulosis Paru. Purwokerto. Jurnal Kesehatan Masyarakat.

Wahyudi Tri Wahid. (2017). Hubungan Perilaku Merokok Dengan Kejadian TB Paru Di Puskesmas Rawat Inap Panjang Tahun 2015. Lampung. Jurnal Kesehatan Holistik. 